\title{
AGROCYBE PUTAMINUM (AGARICALES, BASIDIOMYCOTA), NEW FOR POLAND
}

\author{
Marek Halama
}

\begin{abstract}
Agrocybe putaminum (Maire) Singer, a species hitherto unknown in Poland, is reported from two localities in the southwestern part of the country, with descriptions and illustrations of the morphological characters of the newly collected basidiomata. The delimitation of A. putaminum is briefly discussed, and information on the ecology of the fungus and its world distribution is provided.
\end{abstract}

Key words: Agrocybe sororia complex, alien species, distribution, Naucoria putaminum, micromorphology, Polish mycobiota Marek Halama, Museum of Natural History, Wrocław University, ul. Sienkiewicza 21, 50-335 Wrocław, Poland; e-mail: marek.halama@uwr.edu.pl

\section{INTRODUCTION}

The genus Agrocybe was introduced by Fayod (1889) and consists of agaricoid fungi producing small to large stipitate basidiomata with attached lamellae and with or without a partial veil and annulus. The species within this genus have a dull brown spore print, cellular structure of the pileipellis (a hymeniderm or ixohymeniderm) and distinct hymenial cystidia. These saprotrophs occur on soil, litter and wood, rarely on dung (Nauta 2005; Ryman 2008). Agrocybe has traditionally been placed in the Bolbitiaceae, which has been abandoned by some authors recently (Walther \& Weiß 2006; Tóth et al. 2013). Molecular phylogenetic analyses have suggested that the genus as presently defined is polyphyletic (Moncalvo et al. 2002; Walther et al. 2005; Tóth et al. 2013). This has also been supported by anamorphic characters (Walther \& Weiß 2006).

Agrocybe has a widespread distribution and is represented by $\mathrm{ca} 100$ species worldwide (Watling 1981; Singer 1986; Kirk et al. 2008). A summary of the species diversity of this genus in Poland as known up to the beginning of the $21^{\text {st }}$ century was given by Wojewoda (2003). Until now Agrocybe was represented in Poland by 12 species (Wojewoda 2003; Kujawa \& Gierczyk 2007). During field work in southwestern Poland (2009-2011) I found Agrocybe putaminum (Maire) Singer, a species new for Poland. In this paper, basidiomata of $A$. putaminum collected in on the Równina Oleśnicka plain and Wzniesienia Gubińskie heights are described, and information on the ecology and world distribution of the species is briefly summarized. The features that distinguish $A$. putaminum from related taxa are also presented.

\section{Material AND METHODS}

Macroscopic features were studied from fresh material of four collections comprising 30 basidiomata in different stages of development. Microcharacters were observed with a Nikon Eclipse E-400 light microscope equipped with a Nikon digital camera (DS-Fi1). All microscopic structures were observed on preparations from dried material. Freehand sections of rehydrated pieces of basidiomata were examined in $5 \% \mathrm{NH}_{3} \cdot \mathrm{H}_{2} \mathrm{O}$ and Congo red reagent. Image-grabbing and biometric analyses were done with NIS-Elements D 3.1 imaging software. Dimensions of microcharacters are given as (minimum) mean \pm standard deviation (maximum), and additionally in the form of the main data range (10-90 percentile values). The $\mathrm{Q}$ value represents the length/width ratio of basidiospores. For basidiospore size measurements, randomly selected mature spores 
were measured without the hilar appendix. The length of basidia was measured excluding sterigmata. Micrographs were taken with a digital camera. Statistical computations employed Statistica software (StatSoft). Morphological terminology follows Vellinga (1988) and Vellinga and Noordeloos (2005). The studied collections are deposited in the Museum of Natural History, Wrocław University, Wrocław, Poland (WRSL).

\section{RESULTS AND DISCUSSION}

Agrocybe putaminum (Maire) Singer Figs 1-3

Beih. Botan. Centralbl., Abt. B 56: 167. 1936 - Naucoria putaminum Maire, Ann. Mycol. 11(4): 350. 1913.

Illustrations: Maire (1913: plate 16, fig. 8-17), Bas (1958: 140, fig. 2a-g), Colin and Josserand (1967: 444, fig. 1), Nauta (1987: plates 24-27), Rald (1989: 40, fig. 2), Gulden (1997: 8, fig. 4), de Haan (1998: 92, fig. 1-6), La Chiusa (1998: 326, photo; 327, fig. A-F), Pegler and Legon (1998: 60, photo), Ludwig (2000: 5, fig. 1.6A-C), Shaw and Kibby (2001: 10, photo), Nauta (2005: 216, fig. 210), Vellinga (2008: 5, fig. 1; 38, fig. 2).

Basidiomata growing solitary, gregarious or in clumps but not caespitose. Pileus $20-70 \mathrm{~mm}$, initially conical, truncately broadly conical, then convex, after which plano-convex, not hygrophanous, with inflexed to deflexed margin when young, later straight to rarely reflexed margin, ochraceous to yellow brown, dry, initially velvety, then glabrous, smooth or sometimes \pm wrinkled. Lamellae, L = 30-60, 1 = 2-6, crowded, narrowly adnate to adnate, sometimes emarginate with decurrent tooth, subsegmentiform, subventricose to ventricose, first pale yellow-brown, then brown, with concolorous or whitish edge. Stipe 25-90 $\times$ 3.0-9.0 $\mathrm{mm}$, not annulate, cylindrical, tapering upwards to subclavate, generally \pm swollen to bulbous towards base (up to $13 \mathrm{~mm}$ broad), straight or bent, at first stuffed, later fistulose, strongly fibrillose, pale yellow, pale yellow-brown to yellow-brown, darker on handling, strongly fibrillose, dark brown granulose-flocculose (especially in lower half), usually with white rhizomorphs. Context firm, whitish to pale brown, darkening when cut (especially at base of stipe). Taste and smell distinctly mealy (farinaceous). Spore deposit not obtained.
Basidiospores (9.6) $11.7 \pm 0.7(13.8) \times(5.7)$ $7.0 \pm 0.4(8.2) \mu \mathrm{m}, 10.8-12.6 \times 6.6-7.4 \mu \mathrm{m}$, $\mathrm{Q}=(1.3) 1.7 \pm 0.1$ (2.2), $\mathrm{Q}=1.5-1.8, \mathrm{n}=412$, ellipsoid to oblong (frequently with adaxial side slightly less convex than abaxial side), smooth, moderately thick-walled up to $0.8 \mu \mathrm{m}$, with apical germ pore up to $1.2 \mu \mathrm{m}$ wide, yellow-brown in ammonia. Basidia (24.6) $33.8 \pm 3.5(42.2) \times(7.9)$ $10.6 \pm 1.1(13.5) \mu \mathrm{m}, 29.8-37.9 \times 9.3-12.2 \mu \mathrm{m}$, $\mathrm{n}=72$, narrowly clavate, 4 -spored. Cheilocystidia (31.9) $44.5 \pm 6.7(63.9) \times(8.3) 11.1 \pm 1.3(14.9)$ $\times(4.6) 6.6 \pm 1.0(9.3) \mu \mathrm{m}, 36.2-53.6 \times 9.7-12.8$ $\times 5.3-7.8 \mu \mathrm{m}, \mathrm{n}=101$, mostly lageniform to narrowly utriform (sometimes subcapitate), rarely clavate, sometimes with yellow-brown refractive content, thin-walled. Pleurocystidia (23.0) $38.9 \pm$ $7.7(56.9) \times(13.5) 19.2 \pm 3.1(27.0) \times(6.7) 13.4$ $\pm 3.4(21.3) \mu \mathrm{m}, 29.0-48.0 \times 14.9-23.5 \times 9.4$ $17.7 \mu \mathrm{m}, \mathrm{n}=61$, scattered to abundant, narrowly to broadly utriform or clavate, sometimes with crystals at apex and with yellowish brown refractive content, thin-walled. Pileipellis an irregular hymeniderm with transitions to an epithelium of erect, irregularly clavate, elements (not measured). Pigment pale yellow to brown, encrusting or parietal. Pileocystidia scattered to abundant, (21.1) $45.1 \pm 10.4(75.7) \times(5.8) 9.8 \pm 2.0(16.1)$ $\times(3.1) 5.4 \pm 1.0(7.8) \mu \mathrm{m}, 34.2-59.3 \times 7.6-12.5$

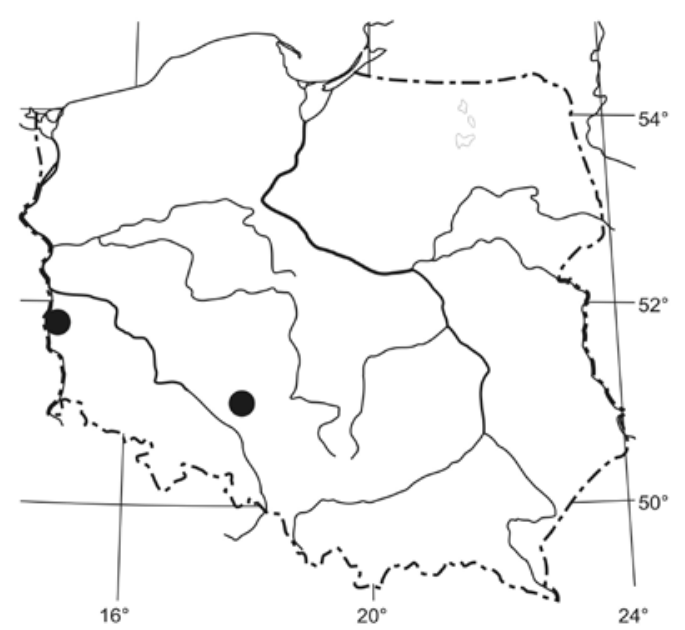

Fig. 1. Known distribution of Agrocybe putaminum (Maire) Singer in Poland. 
$\times 4.1-6.8 \mu \mathrm{m}, \mathrm{n}=101$, lageniform to utriform, sometimes subcapitate, thin-walled. Caulocystidia abundant, clustered, (28.6) $46.9 \pm 8.9$ (75.2) $\times(8.0) 12.3 \pm 2.0(19.5) \times(3.2) 5.8 \pm 1.1(8.8) \mu \mathrm{m}$, $37.2-58.2 \times 10.1-14.8 \times 4.5-7.2 \mu \mathrm{m}, \mathrm{n}=101$, usually lageniform, rarely utriform, usually with brown content, thin-walled. Clamp-connections rather scarce, observed at base of basidia.

Specimens examined: POLAND. Równina OleŚNICKA PLAIN: Domaszowice village, arable field, on well rotted manure mixed with straw and soil, alt. $166 \mathrm{~m}$ a.s.1., $51^{\circ} 2^{\prime} 44^{\prime \prime} \mathrm{N}, 17^{\circ} 53^{\prime} 5^{\prime \prime} \mathrm{E}, 8$ June 2009 , leg. M. Halama (WRSL HM-2009-0152), 13 June 2009, leg. M. Halama (WRSL HM-2009-0153), 21 June 2009, leg. M. Halama (WRSL HM-2009-0154); WZNIESIENIA GUBIŃSKIE HEIGHTS: $1.4 \mathrm{~km}$ south of Koło village, arable field, on well rotted manure mixed with straw and soil, alt. $65 \mathrm{~m}$ a.s.1., $\left.51^{\circ} 49^{\prime} 31^{\prime \prime} \mathrm{N}, 14^{\circ} 46^{\prime} 56^{\prime \prime} \mathrm{E}\right), 29$ July 2011, leg. M. Halama (WRSL HM-2011-0001).

Agrocybe putaminum was originally described by Maire (1913) as Naucoria (Fr.) P. Kumm. Later it was transferred to the genus Agrocybe by Singer (1936) and placed in section Microsporae Sing., which groups species with a narrow germ pore (up to $1 \mu \mathrm{m}$ on average) and having pileocystidia (Singer 1986). Macro- and microcharacters of the Polish specimens of $A$. putaminum well match the description and iconography of the species given by Nauta (1987, 2005), La Chiusa (1998) and Pegler and Legon (1998).

Taxonomically $A$. putaminum belongs to the Agrocybe sororia complex of rare species with similar appearance and ecology, which are characterized by the lack of a partial veil, the presence of large, rather inflated, \pm utriform cheilocystidia, and the presence of relatively short, broadly ellipsoid to ovoid basidiospores with a distinct germ pore. Besides $A$. putaminum, the $A$. sororia complex consists of one species known from Japan (A. farinacea Hongo) and four species described from eastern North America [A. amara (Murrill) Singer, $A$. hortensis (Burt) Singer, $A$. smithii Watling \& H. E. Bigelow, A. sororia (Peck) Singer]. Watling and Bigelow (1983) provided a key for the complex and descriptions of all the species that are separated on the basis of differences in the presence, size and shape of cystidia
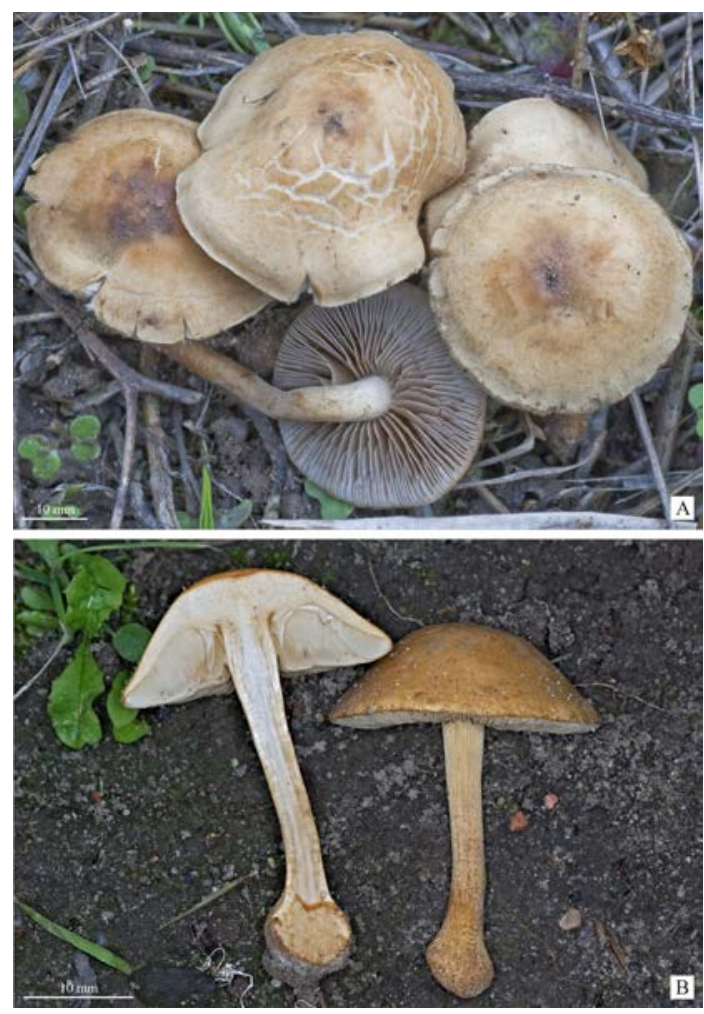

Fig. 2. Basidiomata of Agrocybe putaminum (Maire) Singer (A - WRSL HM-2011-0001, B - HM-2009-0154).

and basidiospores. In general, A. putaminum seems to be well distinguished from the other taxa of the complex by the velvety stipe, which is grooved and almost entirely covered with caulocystidia, the occurrence of both the prominent pileocystidia and pleurocystidia, and (except for $A$. smithii) mostly ellipsoid basidiospores of relatively large size. With its typical yellow-brown color and the size of the basidiomata, A. putaminum superficially bears a certain resemblance to $A$. praecox (Pers.: Fr.) Fayod s.l., A. dura (Bolton) Singer and $A$. rivulosa Nauta. The species of section Agrocybe mentioned above, however, differ generally in being annulate, lacking pileocystidia and having a less conspicuous germ pore.

In Europe A. putaminum is considered as alien taxon from outside the continent (Anonymous 2009). According to Shaw and Kibby (2001) and Kibby (2011) this species most probably has its origin in North America, but the alien status of 


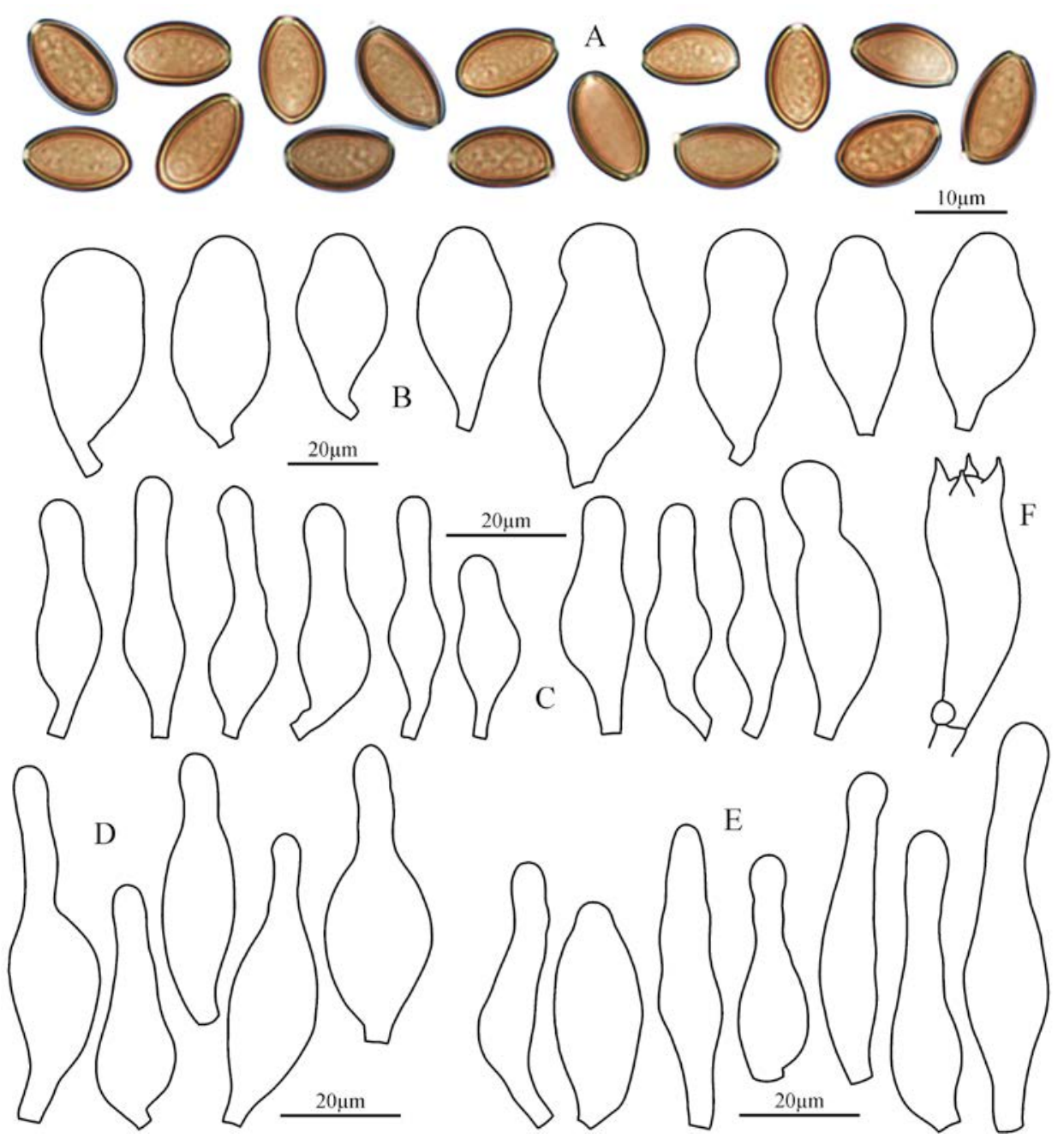

Fig. 3. Agrocybe putaminum (Maire) Singer. A - basidiospores, B - pleurocystidia, C - cheilocystidia, D - caulocystidia, E - pileocystidia, F - basidium (all photographed and traced from WRSL HM-2011-0001).

A. putaminum is open to question, and there is no clear evidence for the American origin of the fungus. This saprotrophic species was first recorded from a garden in eastern France (Conflans-sur-Lanterne), where it was observed growing on buried stones of plums (Prunus) and cherries (Cerasus) (Maire 1913). Then early in the 1950s the species was found again in southwestern Germany (Saarbrücken). On this occasion it was observed in a riparian deciduous forest on bare soil, rich in wood remains (Derbsch 1976). Between 1956 and 1970 the first specimens of $A$. putaminum were found in the Netherlands (Leiden, Amsterdam, Alkmaar). At that time, the species was observed in a school garden on soil mixed with partly decayed dung and straw and on sandy clay, both without fruits of members of the Rosaceae, and on wood chips along a footpath in a recreational park (Bas 1958; van den Bergh 1970). Late in the 1960s this fungus was found again in France in Lyon and in Givors. On this occasion it was observed on rubbish, including fine woody debris (shavings, woodchips?) at a place used as a public dump, and on a rotten straw layer covering soil in 
a cherry orchard (Colin \& Josserand 1967, 1968). In Belgium (Antwerp) A. putaminum probably first appeared in 1970 (Bogaerts 2015).

For a long time this species was considered a mycological rarity found only at a few sites (Bas 1958), but as soon as $A$. putaminum made the substrate jump from fruit stones to wood chips it begun to spread more rapidly on the continent (Vellinga 2008). Over the period from 1913 to 1970 this fungus has been reported from about a dozen sites located in four countries. Since 1971 it has been reported from at least 85 sites located in 11 European countries (Belgium, Denmark, England, Finland, Germany, Italy, Luxembourg, the Netherlands, Norway, Sweden, United Kingdom) (e.g., Nauta 1986; Kreisel 1987; Rald 1989; Krieglsteiner 1991; Legros 1996; Tholl 1996; Legon et al. 2005; Onofri 2005; Walleyn et al. 2006; Ryman 2008). It wasn't until some 90 years later, in the early 2000 s, that $A$. putaminum was found outside Europe for the first time. New observations and collections were made in western North America in the San Francisco Bay area (Vellinga 2008), in south-central Turkey's Karaman Province (Doğan et al. 2003; Sesli \& Denchev 2008), and in Australia and New Zealand (http://www.gbif. org/species/2533207).

The collections of $A$. putaminum from Poland are from two anthropogenic habitats separated by ca $230 \mathrm{~km}$. In both cases the observed species was scattered over large areas of arable fields where maize cultivation took place. Its basidiomata were collected from well rotted manure mixed with straw and soil. Although A. putaminum produces sporocarps throughout the whole season in Europe (it has been found in numbers from April to December), the majority of its finds are from June, July and August ( $77 \%$ of available records). This seasonal tendency is also characteristic for the material from Poland. Agrocybe putaminum is considered to be an alien species here, as mycologists have been active in these regions since the late $1800 \mathrm{~s}$ and it is unlikely that they would not have noticed such a conspicuous fungus. The occurrence of the species only in man-made habitats constitutes an additional argument in favor of this last idea. The question of how A. putaminum reached Poland is more problematic. It is not just a matter of where it originated but also how it arrived. These questions are beyond the scope of this study, but both active drivers (e.g., changes in agricultural practices) and passive drivers (e.g., climatic changes) of its emergence cannot be excluded.

Agrocybe putaminum is redlisted in some countries such as Denmark and the Netherlands (Arnolds \& Veerkamp 2008; Anonymous 2012) even though it has been expanding its range in Europe. Recently this fungus has been encountered mostly in gardens, orchards, parks, roadside verges and lanes of trees, in roadside planting schemes, composted flowerbeds, and on ruderal sites, rarely in non-anthropogenic habitats (forests). The number of its records in rural areas contrasts with the vast number of records from urban areas (e.g., Kirk $\&$ Cooper 2015). Although A. putaminum colonizes a variety of substrates (e.g., bare soil rich in wood remains, composted soil, soil intermixed with partly decayed manure and straw, wood remains, mulch material), it can be concluded that concentrations of wood mulch material are currently the principal habitat for this species (e.g., de Haan 1998; Arnolds $\&$ van den Berg 2005). The mulch material (wood chips, bark chips, woodchip mulch, composted soil) as substrate presumably favor the spread of this species, which appears to be rapidly expanding its range and currently seems to be a frequent and abundant member of woodchip communities (Henrici 2000; Shaw \& Kibby 2001; Legon et al. 2005).

AcKNowledgements. I am grateful to Bernadeta Pawlik (Cracow, Poland) and Marta Lange (Wrocław, Poland) for their kind help in completing the mycological literature, and two anonymous reviewers for their very constructive comments. The study was supported in part by the statutory fund of the Museum of Natural History, University of Wrocław.

\section{REFERENCES}

AnOnymous 2009. List of species alien in Europe and to Europe. In: DAISIE (ed.), Handbook of alien species in Europe, pp. 133-263. Springer, Netherlands.

AnOnYmous 2012. The Danish Red Data Book. [June 2012]. Published on the WEB site: http://www.dmu.dk/en/animalsplants/red_data_book/. 
Arnolds E. \& VAN den Berg A. 2005. The rise of fungi on woodchips. Coolia 48(3): 131-148.

Arnolds E. \& Veerkamp M. 2008. Basisrapport Rode Lijst Paddenstoelen. Nederlandse Mycologische Vereniging, Utrecht.

Bas C. 1958. Notes on Agaricales I. Blumea, Suppl. 4: 138-143.

BogaerTs A. 2015. The BR Herbarium Catalogue (Herbarium Mycologicum). [July 2015]. Botanic Garden Meise, http:// www.br.fgov.be/RESEARCH/COLLECTIONS/HERBARIUM/.

Colin M. \& Josserand M. 1967. Recolte a Lyon meme d'un rare Agrocybe: A putaminum (Maire) Singer. Bull. Mens. Soc. Linn. Lyon 36: 443-447.

Colin M. \& Josserand M. 1968. Une quatrième station d'Agrocybe putaminum (Maire) Singer. Bull. Mens. Soc. Linn. Lyon 37: 365-367.

DE HAAn A. 1998. Een explosieve groei van Agrocybe putaminum (Maire) Singer (Fluweelleemhoed). AMK Mededelingen 3(1998): 92-94.

Derbsch H. 1976. Seltene Agaricales-Arten aus dem Saarland. Z. Pilzk. 42: 161-168.

DoĞan H. H., KaşıK G., Öztürk C. \& Aktaş S. 2003. New records in Coprinaceae and Bolbitiaceae from Karaman Province. Ot Sist. Bot. Derg. 10(1): 111-141.

FAYOD V. 1889. Prodrome d'une histoire naturelle des Agaricinés. Ann. Sci. Nat., Bot., Sér. 7(9): 181-411.

GuLDEN G. 1997. To nyinnvandrere i Norges funga (soppflora): Kjempekjeglesopp (Conocybe intrusa (Peck) Singer) og Agrocybe putaminum (Maire) Singer. Blekksoppen 25(72): 3-9.

Henrici A. 2000. Notes and records. Field Mycol. 1(4): 135$136 \& 144$.

KIBBy G. 2011. ENHS Meeting notes: Invasion of the Aliens: Climate change and invasive species in Britain, 14 September 2011. Elmbridege Natural History Society Bulletin 291. http://492779914656210597.weebly.com.

KIRK P. M. \& CoOper J. A. 2015. The GB checklist of fungi - species data. British Mycological Society. [July 2015]. http://www.fieldmycology.net/ GBCHKLST/.

Kirk P. M., Cannon P. F., Minter D. V. \& Stalpers J. A. 2008. Ainsworth \& Bisby's Dictionary of Fungi. $10^{\text {th }}$ ed. CAB International, Wallingford.

Kreisel H. (ed.) 1987. Pilzflora der Deutschen Demokratischen Republik. Basidiomycetes (Gallert-, Hut- und Bauchpilze). VEB Gustav Fischer Verlag, Jena.

Krieglsteiner G. J. 1991. Verbreitungsatlas der Großpilze Deutschlands (West). 1. Eugen Ulmer GmbH \& Co., Stuttgart.

Kujawa A. \& GierczyK B. 2007. Register of protected and endangered fungi species. Part II. A list of species recorded in 2006 year. Przeglad Przyrodniczy 18(3-4): 3-70 (in Polish with English summary).
La Chiusa L. 1998. Agrocybe putaminum. $1^{\circ}$ contributo alla conoscenza di specie interessanti del parco di Monza. Riv. Micol. 4: 325-328.

Legon N. W., Henrici A., Roberts P., Spooner B. M. \& Watling R. 2005. Checklist of the British and Irish Basidiomycota. Royal Botanic Gardens, Kew.

Legros J. P. 1996. Agrocybe putaminum (Maire) Singer. Bull. Soc. Mycol. France 112: 155-159 \& pl. 313.

Ludwig E. 2000. Pilzkompendium. 1: Abbildungen. Die kleineren Gattungen der Makromyzeten mit lamelligem Hymenophor aus den Ordnungen Agaricales, Boletales und Polyporales. IHW-Verlag, Eching.

MaIre R. 1913. Études mycologiques, Fasc. I. Ann. Mycol. 11(4): 331-358.

Moncalvo J.-M., Vilgalys R., Redhead S. A., Johnson J. E., James T. Y., Catherine Aime M., Hofstetter V., VerDUin S. J. W., LARSSON E., BARoni T. J., ThORN G. R., Jacobsson S., Clémençon H. \& Miller O. K. JR 2002. One hundred and seventeen clades of euagarics. Mol. Phylogenet. Evol. 23(3): 357-400.

Nauta M. M. 1986. De in Nederland voorkomende Leemhoeden (Agrocybe). Coolia 29(2): 36-43.

Nauta M. M. 1987. Revisie van de in Nederland voorkomende soorten van het geslacht Agrocybe (Leemhoeden). Rijksherbarium, Leiden.

Nauta M. M. 2005. Agrocybe Fay. In: M. E. Noordeloos, T. W. Kuyper \& E. C. Vellinga (eds), Flora Agaricina Neerlandica. 6: 204-221. CRC Press, Boca Raton.

ONOFri S. (ed.) 2005. Checklist dei funghi italiani. Basidiomycetes. Carlo Delfino, Sassari.

Pegler D. N. \& Legon N. W. 1998. Profiles of Fungi: 92. Agrocybe putaminum (Maire) Sing. Mycologist 12(2): 60.

RALD E. 1989. To for Danmark nye hatsvampe, der vokser på træflis: Stropharia percevalii og Agrocybe putaminum. Svampe 19: 39-43.

Ryman S. 2008. Agrocybe Fayod. In: H. KnUdSen \& J. VesterHOLT (eds), Funga Nordica, pp. 826-830. Nordsvamp, Copenhagen.

Sesli E. \& Denchev C. M. 2008. Checklists of the myxomycetes, larger ascomycetes, and larger basidiomycetes in Turkey. Mycotaxon 106: 65-67.

Shaw P. J. A. \& KibBy G. 2001. Aliens in the flowerbeds. The fungal biodiveristy of ornamental woodchips. Field Mycol. 2(1): 6-11.

Singer R. 1936. Studien zur Systematik der Basidiomyceten. II. Beih. Bot. Centralbl. 56: 157-174.

Singer R. 1986. The Agaricales in modern taxonomy. $4^{\text {th }}$ ed. Koeltz Scientific Books, Koenigstein.

Tholl M.-T. 1996. Notes mycologiques (1986-1995). Bull. Soc. Nat. Luxemb. 97: 119-134. 
Tóth A., Hausknecht A., Krisai-Greilhuber I., PApP T., VÁGVÖLGYI C. \& NAGY L. G. 2013. Iteratively refined guide trees help improving alignment and phylogenetic inference in the mushroom family Bolbitiaceae. PLoS One 8(2): e56143.

VAN DEN Bergh F. A. 1970. Agrocybe putaminum (Maire) Singer in Alkmaar. Coolia 14(5): 129-131.

Vellinga E. C. 1988. Glossary. In: C. Bas, T. W. Kuyper, M. E. Noordeloos \& E. C. Vellinga (eds), Flora Agaricina Neerlandica. 1: 54-64. A. A. Balkema Publishers, Rotterdam.

Vellinga E. C. 2008. Wood chip fungi: Agrocybe putaminum in the San Francisco Bay Area. Fungi 1(4): 5 \& 37-39.

Vellinga E. C. \& Noordeloos M. E. 2005. Glossary. In: M. E. Noordeloos, T. W. Kuyper \& E. C. Vellinga (eds), Flora Agaricina Neerlandica. 6: 5-11. CRC Press, Boca Raton.

Walleyn R., Antonissen I., de HaAn A., de HaAn M., de Keyser J., Hendrickx H., Lachapelle J., Le Jeune G., Mervielde H., Noten L., Schoutteten J., van de Kerckhove O., van de Put K., Verbeken A., Volders J., Lenaerts L., Monnens J., Termonia W., Van der Veken P.,
Van Ryckegem G., Vandeven É., Beker H., Bogaerts A., De Kesel A., De Pauw S., Dielen F., Ghyselinck D., Hanssens C. \& Vannieuwerburgh L. 2006. Standaardlijst van Basidiomycota en Myxomycota van Vlaanderen en het Brussels Gewest. In: R. WALleyn \& É. VANDEVEN (eds). Standaardlijst van Basidiomycota en Myxomycota van Vlaanderen en het Brussels Gewest. Rapport INBO.R.2006.27, pp. 1-143 + errata. Instituut voor Natuuren Bosonderzoek, Brussel.

Walther G. \& Weiss M. 2006. Anamorphs of the Bolbitiaceae (Basidiomycota, Agaricales). Mycologia 98(5): 792-800.

Walther G., Garnica S. \& Weiss M. 2005. The systematic relevance of conidiogenesis modes in the gilled Agaricales. Mycol. Res. 109(5): 525-544.

WatLING R. 1981. Census catalogue of world memebrs of the Bolbitiaceae. Bibl. Mycol. 82: 1-224.

Watling R. \& Bigelow H. E. 1983. Observations on the Bolbitiaceae - 22. Mycotaxon 17: 377-397.

WoJewoda W. 2003. Checklist of Polish larger Basidiomycetes. Biodiversity of Poland 7. W. Szafer Institute of Botany, Polish Academy of Sciences, Kraków. 